\title{
IMPACT OF COVID-19 ON EDUCATION OF UNDERGRADUATE MEDICAL STUDENTS OF PAKISTAN
}

\author{
Nauman Aziz ${ }^{a}$, Muhammad Waseem ${ }^{b}$, Anmol Fatima ${ }^{c}$, Aqsa Anwar ${ }^{c}$, Fahad Khalid ${ }^{c}$, Taimoor Asghar \\ ${ }^{a}$ Assistant Professor, Department of Physiology, Sahiwal Medical College Sahiwal. \\ ${ }^{b}$ Assistant Professor and Head Department of Pulmonology, Sahiwal Medical College Sahiwal. \\ 'Medical Student 4th Year Sahiwal Medical College Sahiwal.
}

\begin{abstract}
:
BACKGROUND \& OBJECTIVE: COVID-19 has caused unrest among medical students all over the world including Pakistan. The objective of this study was to assess the impact of COVID-19 on education of undergraduate medical students of Pakistan by assessing their responses to a survey.
\end{abstract}

METHODOLOGY: A validated questionnaire of this cross-sectional analytical study was distributed among 900 undergraduate MBBS students of different medical colleges and universities across Pakistan. Results were assessed by using SPSS version-24.

RESULTS: The response rate of our study was $85 \%$. Majority of the participants were females (64.4\%) while the fourth year MBBS students took part in the survey with the highest number of students, $434(56.7 \%)$. Major part of the participants $(90.8 \%)$ agreed to the fact that COVID-19 has affected their study duration. Ninety six percent of the students had online classes during this COVID-19 but more than half of the students (52.8\%) were of the view that it's hardly effective. Interestingly $91.5 \%$ of the students participating in the survey showed that they have lost interest in studies. A great difficulty was faced by the students in establishing boundaries between work and home (84.0\%). Almost eighty five percent of the students missed their classroom environments.

CONCLUSION: There is a huge impact of COVID-19 on medical education of the students in Pakistan. It affected them both physically and mentally and created great phobia in them related to future of their education.

KEY WORDS: Undergraduate MBBS students, COVID-19, Survey.

How to cite this:

doi: https://doi.org/10.37723/jumdc.v11i4.448

Aziz N, Waseem M, Fatima A, Anwar A, Khalid F, Asghar T. IMPACT OF COVID-19 ON EDUCATION OF UNDERGRADUATE MEDICAL STUDENTS OF PAKISTAN. jumdc. 2020;11(4):7-15.

doi: https://doi.org/10.37723/jumdc.v11i4.448

This is an Open Access article distributed under the terms of the Creative Commons Attribution License (http://creativecommons.org/licenses/by/4.0), which permits unrestricted use, distribution, and reproduction in any medium provided the original work is properly cited. 


\section{INTRODUCTION:}

The Corona Virus Disease-2019 (COVID-19) pandemic caused by novel coronavirus known as SARS-CoV-2 (formerly called 2019-nCoV) has become global health emergency and the greatest challenge of the present time. The first case of COVID-19 was reported in Wuhan City, Hubei State of China in December 2019 and then it erupted and unrolled with tremendous speed ${ }^{[1]}$. The virus infected more than 118000 people and caused 4291 deaths in 114 countries within 3 months and WHO declared it a pandemic ${ }^{[2]}$. This pandemic followed no boundaries and caused catastrophic effect that spanned the globe. On January $13^{\text {th }}, 2020$ Thailand recorded first case outside the mainland China and then continued to spread throughout the globe ${ }^{[3]}$. Italy was hit badly by COVID-19 with highest mortality. In Pakistan, first case of COVID-19 was reported by ministry of Health on 26 Feb, 2020 after which it spread swiftly all over the Pakistan ${ }^{[4]}$. The world is still witnessing its spread due to which countries are facing disastrous social, economic and political crisis. Particularly it is affecting already trembling economy of developing countries like Pakistan. Despite of direct burden over health sector, the pandemic has also affected the ways humans facing the world in different ways ranging from transportation to social events including the lifestyle ${ }^{[5]}$.

The novel COVID-19 pandemic has hit medical education seriously. Worldwide, the suspension of formal classes of MBBS in the wake of COVID19 pandemic precipitated a tremendous spike in uncertainty among medical community ${ }^{[2]}$. Due to suspension of classes it was a challenge for medical faculty to re-engage students in study. The COVID-19 pandemic forced a rapid switch to technology to provide students a platform to certify their participation in study during pandemic. The implementation of online forum for study has given a unique method to facilitate the students during pandemic ${ }^{[6]}$. To alleviate viral transmission and to prevent the exposure of medical students to COVID-19 medical colleges and universities have also cancelled clinical work for students. This loss of clinical attachment is raising alarm about the future performance of medical students in wards and causing great confusion among students

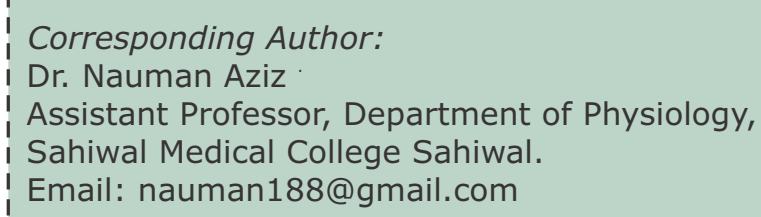

regarding how to proceed during pandemic. Due to this, students are losing opportunities for enhancement of their clinical skills. This situation is particularly troublesome for students of clinical years like final year and fourth year MBBS ${ }^{[7]}$.

Unfortunately, the situation is worse in Pakistan where loss of collaboration, no ward rotation and lack of facilities to integrate with technology is highlighting the irreplaceable value of face to face or class room study and most of students are not equipped fully to cope up with this online system of study ${ }^{[7]}$. In addition the knowledge regarding COVID-19 is not upto mark in our population ${ }^{[8]}$. Considering all these problems and ongoing efforts of online classes and assignments managed by our medical educational institutes, we tried to analyze the impact of these efforts which are introduced in consequences of pandemic on medical education by conducting survey over more than 750 medical undergraduates studying in different medical colleges of Pakistan.

\section{METHODOLOGY:}

This cross-sectional analytical study was conducted at Sahiwal Medical College Sahiwal from $15^{\text {th }}$ June to $15^{\text {th }}$ July 2020. This web-based cross-sectional survey was conducted after taking ethical approval from institutional review board of Sahiwal Medical College Sahiwal via letter No. 101/DME/SLMC/SWL. Sample size was calculated by using following formula;

$$
\text { Sample size }=\frac{Z_{1-\alpha / 2^{2}} p(1-p)}{d^{2}}
$$

$Z_{1-\mathrm{a} / 2}=$ is standard normal variate (at $5 \%$ type 1 error $(p<0.05)$ it is 1.96 . As in majority of studies $p$-values are considered significant below 0.05 hence 1.96 is used in formula ${ }^{[9]}$. A validated questionnaire was sent to 900 MBBS students of different medical colleges and universities across Pakistan through Whatsapp 
and Facebook messenger. Medical college and universities where the questionnaire were sent belonged to different cities of Pakistan including Lahore, Islamabad, Karachi, Quetta, Peshawar, Sahiwal, Multan, Bolan, Bahawalpur and Faisalabad. Such online soft wares were used to make sure that social distancing is maintained due to COVID-19 while conducting this survey. Only undergraduate MBBS students were included in the survey while allied health sciences students, graduate and post graduate students were excluded. Convenient sampling technique was used.

Data were calculated by using SPSS version 24 . Frequencies and percentages of different demographic characteristics and responses of students were tabulated. Significance of the data was checked by Chi-Square test. Significance was taken at $p<0.05$.

\section{RESULTS:}

The questionnaire was sent to 900 undergraduate MBBS students of different medical colleges across Pakistan and out of which 765 responded; hence the response rate of our survey was $85 \%$. Majority of the participants were females, 493(64.4\%). Fourth year MBBS students took part in the survey with the highest number of students, 434 (56.7\%). Third year was second on the list with 131 students $(17.1 \%)$. Final year MBBS students responded with least number of students '42 $(5.5 \%)^{\prime}$. An overwhelming of students was resident of urban areas, $612(80.0 \%)$ while remaining belonged to rural areas. As far as the participation of the institutions across Pakistan is concerned, Sahiwal Medical College Sahiwal participated with maximum no. of students, 254 (33.20\%). 58 (7.5\%) undergraduate MBBS students of Allama Iqbal Medical College Lahore participated. Next on the list were the students of Sargodha medical College Sargodha, 48 $(6.2 \%)$ and $\mathrm{CMH}$ Lahore, $23(4.1 \%)$. Rests of the students were from other institutions, 382 (49.9\%) (Table-I).

The impact of COVID-19 on medical education of undergraduate MBBS students was assessed by a validated questionnaire. We calculated the frequencies and percentages of the responses. Major part of the participants $(90.8 \%)$ agreed to the fact that COVID-19 has affected their study duration. This was also proved by the fact that $75.4 \%$ of the survey participants were of the view that this pandemic has caused more wastage of time. Many students $(89.8 \%)$ were found to be concerned about their professional exam due to current situation. The ward rotation of the MBBS students was also severely affected by the pandemic (67.3\%)(Table- II). Slightly more than half of the participants $(55.4 \%)$ thought about doing some clinical services during pandemic but actually only $6.4 \%$ of the students did any clinical service. Majority (65.1\%) also agreed that their teachers had given them enough information related to COVID-19. Ninety six percent of the students had online classes during this COVID19 but more than half of the students $(52.8 \%)$ were of the view that it's hardly effective. It was also evident by the fact that $69.7 \%$ of the students were unsatisfied with this method of learning. Interestingly $91.5 \%$ of the students participating in the survey showed that they have lost interest in studies. $90.5 \%$ of the students also agreed that increase in social media use has affected their studies. Performance in clinical wards would also be affected by this pandemic according to $89.8 \%$ students. Online assessment as an alternative to the physical exam was also rejected by an overwhelming number of the students (88.0\%). A great difficulty was faced by the students in establishing boundaries between work and home $(84.0 \%)$. Almost eighty five percent of the students missed their classroom environments. Though majority belonged to urban areas but still $86.3 \%$ thought that elearning was not feasible for the students living in rural areas. Human connection with instructors was also missed to a great deal $(80.7 \%)$ by the students. Nearly two third of the students were of the view that students may never come back to the institutions. Students also shared their fears related to this pandemic. Difficulty of studying at home in the current situation was most feared $(39.3 \%)$ by the MBBS students. Deterioration of psychological state due to negative news and events was feared by $17.6 \%$ of the total survey population. Fear of getting sick or passing on the disease to one's relatives was felt by $16.9 \%$ of the total 765 students. Loss of loved one 
(many people stayed abroad due to the closure of borders) was feared by $15.8 \%$ of the students. Finally the fear of losing scholarship due to pandemic was sensed by only $1.2 \%$ of the students (Table- II).

Different prevalence rates were also calculated for different attitude of the students towards pandemic. Prevalence of students' fear during pandemic according to MBBS classes was calculated and it was found out that almost $84 \%$ of the first year students showed that their time is more wasted than others due to this pandemic. The association was also found to be statistically significant $(p=0.045)$ (Table III).
When prevalence rate of students' interest was cross tabulated with MBBS classes then it was found out that $3^{\text {rd }}$ year and final year students lost their interest in the studies with maximum rates (95.4\% and $95.2 \%$ respectively). Though the association was found to be statistically non-significant $(p=0.127)$ (Table- IV).

Students' concern towards the conduction of professional examination was cross tabulated with MBBS classes. Result was statistically nonsignificant $(p=0.197)$ but more than $80 \%$ of the students of all the MBBS classes showed great concern that their professional examinations may be affected due to pandemic (Table-V).

Table-I: Frequency distribution of demographic characteristics among undergraduate. Medical students $(n=765)$.

\begin{tabular}{|c|c|c|c|}
\hline $\begin{array}{c}\text { Demographic } \\
\text { Characteristics }\end{array}$ & Groups & $\mathbf{n}$ & $\mathbf{( \% )}$ \\
\hline \multirow{2}{*}{ Gender } & Male & 272 & 35.6 \\
\hline \multirow{2}{*}{ Class (MBBS) } & Female & 493 & 64.4 \\
\cline { 2 - 4 } & First Year & 59 & 7.7 \\
\cline { 2 - 4 } & Second Year & 99 & 12.9 \\
\cline { 2 - 4 } & Third Year & 431 & 17.1 \\
\cline { 2 - 4 } & Fourth Year & 42 & 56.7 \\
\cline { 2 - 4 } & Final Year & 5.5 \\
\hline
\end{tabular}

Table-II: Frequency Distribution of responses by the participants of the survey $(n=765)$.

\begin{tabular}{|c|c|c|c|c|}
\hline $\begin{array}{l}\text { Sr. } \\
\text { No. }\end{array}$ & Questions & Responses & $\mathbf{n}$ & $\%$ \\
\hline 1 & $\begin{array}{l}\text { Has COVID-19 affected your } \\
\text { study duration }\end{array}$ & $\begin{array}{l}\text { Yes } \\
\text { No }\end{array}$ & $\begin{array}{c}695 \\
70\end{array}$ & $\begin{array}{c}(90.8 \%) \\
(9.2 \%)\end{array}$ \\
\hline 2 & The pandemic has & $\begin{array}{l}\text { 1. Caused wastage of time } \\
\text { 2. Given you extra time to improve } \\
\text { your concept }\end{array}$ & $\begin{array}{l}577 \\
188\end{array}$ & $\begin{array}{l}(75.4 \%) \\
(24.6 \%)\end{array}$ \\
\hline 3 & $\begin{array}{l}\text { Are you concerned about your } \\
\text { professional exam due to } \\
\text { current situation }\end{array}$ & $\begin{array}{l}\text { Yes } \\
\text { No }\end{array}$ & $\begin{array}{c}687 \\
78\end{array}$ & $\begin{array}{l}(89.8 \%) \\
(10.2 \%)\end{array}$ \\
\hline 4 & $\begin{array}{l}\text { How much this pandemic } \\
\text { affected clinical work due to no } \\
\text { ward rotation }\end{array}$ & $\begin{array}{l}\text { No effect } \\
\text { Mild } \\
\text { Moderate } \\
\text { Severe } \\
\end{array}$ & \begin{tabular}{c|}
60 \\
40 \\
150 \\
515 \\
\end{tabular} & $\begin{array}{l}(7.8 \%) \\
(5.2 \%) \\
(19.6 \%) \\
(67.3 \%)\end{array}$ \\
\hline 5 & $\begin{array}{l}\text { During pandemic did you think } \\
\text { you should do some clinical } \\
\text { service }\end{array}$ & $\begin{array}{l}\text { Yes } \\
\text { No }\end{array}$ & $\begin{array}{l}424 \\
341\end{array}$ & $\begin{array}{l}(55.4 \%) \\
(44.6 \%)\end{array}$ \\
\hline 6 & $\begin{array}{l}\text { Did you do some clinical service } \\
\text { in pandemic }\end{array}$ & $\begin{array}{l}\text { Yes } \\
\text { No }\end{array}$ & $\begin{array}{c}49 \\
716 \\
\end{array}$ & $\begin{array}{l}(6.4 \%) \\
(93.6 \%)\end{array}$ \\
\hline
\end{tabular}




\begin{tabular}{|c|c|c|c|c|}
\hline 7 & $\begin{array}{l}\text { Do you think clinical service will } \\
\text { impact on your medical } \\
\text { education }\end{array}$ & $\begin{array}{l}\text { Yes } \\
\text { No }\end{array}$ & $\begin{array}{l}628 \\
137\end{array}$ & $\begin{array}{l}(82.1 \%) \\
(17.9 \%)\end{array}$ \\
\hline 8 & $\begin{array}{l}\text { Have your teachers given you } \\
\text { enough information about the } \\
\text { disease }\end{array}$ & $\begin{array}{l}\text { Yes } \\
\text { No }\end{array}$ & $\begin{array}{l}498 \\
267\end{array}$ & $\begin{array}{l}(65.1 \%) \\
(34.9 \%)\end{array}$ \\
\hline 9 & Do you have online classes & $\begin{array}{l}\text { Yes } \\
\text { No }\end{array}$ & $\begin{array}{c}740 \\
25\end{array}$ & $\begin{array}{c}(96.7 \%) \\
(3.3 \%)\end{array}$ \\
\hline 10 & $\begin{array}{l}\text { How much effective is the } \mathrm{E}- \\
\text { learning }\end{array}$ & $\begin{array}{c}\text { Not effective at all } \\
\text { Somehow effective } \\
\text { Quite a lot }\end{array}$ & $\begin{array}{c}294 \\
404 \\
67\end{array}$ & $\begin{array}{c}(38.4 \%) \\
(52.8 \%) \\
(8.8 \%)\end{array}$ \\
\hline 11 & $\begin{array}{l}\text { Are you satisfied with this } \\
\text { method of learning during } \\
\text { COVID-19 pandemic }\end{array}$ & $\begin{array}{l}\text { Yes } \\
\text { No }\end{array}$ & $\begin{array}{l}232 \\
533\end{array}$ & $\begin{array}{l}(30.3 \%) \\
(69.7 \%)\end{array}$ \\
\hline 12 & I am of the opinion that & $\begin{array}{l}\text { Students are more interested now } \\
\text { Students have lost interest in } \\
\text { studies }\end{array}$ & $\begin{array}{c}65 \\
700\end{array}$ & $\begin{array}{l}(8.5 \%) \\
(91.5 \%)\end{array}$ \\
\hline 13 & $\begin{array}{l}\text { Transition increase use of social } \\
\text { media have affected your study }\end{array}$ & $\begin{array}{l}\text { Yes } \\
\text { No }\end{array}$ & $\begin{array}{c}692 \\
73\end{array}$ & $\begin{array}{c}(90.5 \%) \\
(9.5 \%)\end{array}$ \\
\hline 14 & $\begin{array}{l}\text { Do you think that E-learning } \\
\text { would be real substitute }\end{array}$ & $\begin{array}{l}\text { Yes } \\
\text { No }\end{array}$ & $\begin{array}{l}104 \\
661 \\
\end{array}$ & $\begin{array}{l}(13.6 \%) \\
(86.4 \%)\end{array}$ \\
\hline 15 & $\begin{array}{l}\text { Concerned about future } \\
\text { performance in wards }\end{array}$ & $\begin{array}{l}\text { Yes } \\
\text { No }\end{array}$ & $\begin{array}{c}687 \\
78\end{array}$ & $\begin{array}{l}(89.8 \%) \\
(10.2 \%)\end{array}$ \\
\hline 16 & $\begin{array}{l}\text { Do you think online assessment } \\
\text { is good alternative to physical } \\
\text { exam }\end{array}$ & $\begin{array}{l}\text { Yes } \\
\text { No }\end{array}$ & $\begin{array}{c}92 \\
673\end{array}$ & $\begin{array}{l}(12.0 \%) \\
(88.0 \%)\end{array}$ \\
\hline 17 & $\begin{array}{l}\text { Are you facing difficulty in } \\
\text { establishing boundary between } \\
\text { work and home }\end{array}$ & $\begin{array}{l}\text { Yes } \\
\text { No }\end{array}$ & $\begin{array}{l}643 \\
122\end{array}$ & $\begin{array}{l}(84.0 \%) \\
(16.0 \%)\end{array}$ \\
\hline 18 & $\begin{array}{l}\text { Do you miss classroom } \\
\text { engagement }\end{array}$ & $\begin{array}{l}\text { Yes } \\
\text { No }\end{array}$ & $\begin{array}{l}633 \\
132\end{array}$ & $\begin{array}{l}(82.7 \%) \\
(17.3 \%)\end{array}$ \\
\hline 19 & $\begin{array}{l}\text { Feasible for students in rural } \\
\text { areas }\end{array}$ & $\begin{array}{l}\text { Yes } \\
\text { No }\end{array}$ & $\begin{array}{l}105 \\
660\end{array}$ & $\begin{array}{l}(13.7 \%) \\
(86.3 \%)\end{array}$ \\
\hline 20 & $\begin{array}{l}\text { Do you miss human } \\
\text { connection with your } \\
\text { instructors }\end{array}$ & $\begin{array}{l}\text { Yes } \\
\text { No }\end{array}$ & $\begin{array}{l}617 \\
148\end{array}$ & $\begin{array}{l}(80.7 \%) \\
(19.3 \%)\end{array}$ \\
\hline 21 & $\begin{array}{l}\text { Worst case scenario that } \\
\text { students may not come } \\
\text { back }\end{array}$ & $\begin{array}{l}\text { Yes } \\
\text { No }\end{array}$ & $\begin{array}{l}432 \\
333\end{array}$ & $\begin{array}{l}(56.5 \%) \\
(43.5 \%)\end{array}$ \\
\hline \multirow[t]{7}{*}{22} & \multirow[t]{7}{*}{ Fear the most } & $\begin{array}{l}\text { 1.Burnout due to overabundance of } \\
\text { information }\end{array}$ & 16 & $(2.1 \%)$ \\
\hline & & $\begin{array}{l}\text { 2. Deterioration of psychological state } \\
\text { due to negative news and events }\end{array}$ & 135 & $(17.6 \%)$ \\
\hline & & $\begin{array}{l}\text { 3. Difficulty of studying at home in the } \\
\text { current situation }\end{array}$ & 301 & $(39.3 \%)$ \\
\hline & & $\begin{array}{l}\text { 4.Fear of getting sick or passing on the } \\
\text { disease to one's relatives }\end{array}$ & 129 & $(16.9 \%)$ \\
\hline & & 5.Fear of losing a scholarship or funding & 9 & $(1.2 \%)$ \\
\hline & & $\begin{array}{l}\text { 6. Loss of earning or loss of income from } \\
\text { parents }\end{array}$ & 54 & $(7.1 \%)$ \\
\hline & & $\begin{array}{l}\text { 7. Loss of loved one (many people stayed } \\
\text { abroad due to the closure of borders) }\end{array}$ & 121 & $(15.8 \%)$ \\
\hline
\end{tabular}


Table-III: Prevalence of Students' Fear during pandemic according to MBBS classes.

\begin{tabular}{|c|c|c|c|c|c|c|c|c|}
\hline & \multicolumn{5}{|c|}{ MBBS Year } & \multirow{2}{*}{$\begin{array}{c}\text { P- } \\
\text { value }\end{array}$} \\
\hline & & & $\begin{array}{l}\text { 1st } \\
\text { Year }\end{array}$ & $\begin{array}{l}\text { 2nd } \\
\text { Year }\end{array}$ & $\begin{array}{l}\text { 3rd } \\
\text { Year }\end{array}$ & $\begin{array}{l}\text { 4th } \\
\text { Year }\end{array}$ & $\begin{array}{l}\text { Final } \\
\text { Year }\end{array}$ & \\
\hline \multirow{4}{*}{$\begin{array}{l}\text { The } \\
\text { pandemic } \\
\text { has }\end{array}$} & Caused wastage of & Count & 49 & 75 & 108 & 311 & 34 & \multirow{4}{*}{0.045} \\
\hline & time & $\%$ & $83.1 \%$ & $75.8 \%$ & $82.4 \%$ & $71.7 \%$ & $81.0 \%$ & \\
\hline & Given you extra & Count & 10 & 24 & 23 & 123 & 8 & \\
\hline & your concept & $\%$ & $16.9 \%$ & $24.2 \%$ & $17.6 \%$ & $28.3 \%$ & $19.0 \%$ & \\
\hline
\end{tabular}

Table-IV: Prevalence of Students' interest during pandemic according to MBBS classes.

\begin{tabular}{|c|c|c|c|c|c|c|c|c|}
\hline & \multicolumn{5}{|c|}{ MBBS Year } & \multirow{2}{*}{$\begin{array}{c}\text { p- } \\
\text { value }\end{array}$} \\
\hline & & & $\begin{array}{c}\text { 1st } \\
\text { year }\end{array}$ & $\begin{array}{l}\text { 2nd } \\
\text { Year }\end{array}$ & $\begin{array}{l}\text { 3rd } \\
\text { Year }\end{array}$ & $\begin{array}{l}\text { 4th } \\
\text { Year }\end{array}$ & $\begin{array}{l}\text { Final } \\
\text { Year }\end{array}$ & \\
\hline \multirow{4}{*}{$\begin{array}{l}\text { I am of the } \\
\text { opinion } \\
\text { that }\end{array}$} & Students are & Count & 9 & 10 & 6 & 38 & 2 & \multirow{4}{*}{0.127} \\
\hline & now & $\%$ & $15.3 \%$ & $10.1 \%$ & $4.6 \%$ & $8.8 \%$ & $4.8 \%$ & \\
\hline & \multirow{2}{*}{$\begin{array}{l}\text { Students have } \\
\text { lost interest in } \\
\text { studies }\end{array}$} & Count & 50 & 89 & 125 & 396 & 40 & \\
\hline & & $\%$ & $84.7 \%$ & $89.9 \%$ & $95.4 \%$ & $91.2 \%$ & $95.2 \%$ & \\
\hline
\end{tabular}

Table-V: Prevalence of Students' Concern during pandemic according to MBBS classes.

\begin{tabular}{|c|c|c|c|c|c|c|c|c|}
\hline & & & \multicolumn{5}{|c|}{ MBBS Year } & \multirow{2}{*}{ p-value } \\
\hline & & & $\begin{array}{l}\text { 1st } \\
\text { Year }\end{array}$ & $\begin{array}{l}\text { 2nd } \\
\text { Year }\end{array}$ & $\begin{array}{l}\text { 3rd } \\
\text { Year }\end{array}$ & $\begin{array}{l}\text { 4th } \\
\text { Year }\end{array}$ & $\begin{array}{l}\text { Final } \\
\text { Year }\end{array}$ & \\
\hline \multirow{4}{*}{$\begin{array}{l}\text { Are you concerned } \\
\text { about your } \\
\text { professional exam }\end{array}$} & \multirow{2}{*}{ No } & Count & 8 & 14 & 13 & 36 & 7 & \multirow{4}{*}{0.197} \\
\hline & & $\%$ & $13.6 \%$ & $14.1 \%$ & $9.9 \%$ & $8.3 \%$ & $16.7 \%$ & \\
\hline & \multirow{2}{*}{ Yes } & Count & 51 & 85 & 118 & 398 & 35 & \\
\hline & & $\%$ & $86.4 \%$ & $85.9 \%$ & $90.1 \%$ & $91.7 \%$ & $83.3 \%$ & \\
\hline
\end{tabular}

\section{DISCUSSION:}

Response rate of our survey was found to be $85 \%$. This was a unique survey conducted among a huge number of students of different medical colleges across different provinces of Pakistan. Students participated in the survey with great zeal and zest and showed their doubts about different aspects of COVID-19. Students from Sahiwal Medical College Sahiwal constituted almost one third of the total participants. It was attributable to the fact that this study was the project of the same college.
Students $(90.8 \%)$ were agreed upon the fact that COVID-19 has affected their studies a lot. A recent study done in Karachi also showed the same result ${ }^{[9]}$. A big wastage of time during COVID-19 is also suggested by majority $(75.4 \%)$ of the participants of the survey. It can be attributable to the fact that students were mentally drained because of the phobia created by COVID-19 ${ }^{[10]}$. Many students $(89.8 \%)$ also showed their concern about their professional examination. There was much news circulating in the media regarding postponement of final exams of MBBS due to 
COVID-19 ${ }^{[11]}$ that caused great unrest among medical students ${ }^{[12]}$. As majority of the study population belonged to higher classes of MBBS (final year, $4^{\text {th }}$ year and third year), so there was a big worry $(86.9 \%)$ among the students that their clinical ward rotation is affected a lot. This concern was also shown by students in a study conducted by Wang et al., ${ }^{[13]}$. Though students agreed that they should do some clinical service in this pandemic yet a bleak number of students actually did some good service clinically in this pandemic $(6.4 \%)$. This difference in thinking and actual work by medical students can be due to many factors like non-availability of proper resources, social distancing and complete lockdown in some areas of Pakistan and noncooperation from their families ${ }^{[14]}$. Majority of our survey population (65.1\%) agreed that the knowledge about COVID-19 was abundantly and precisely given by the teachers. A recent study showed that the faculty members of medical fraternity were a major factor in spreading the correct information related to COVID-19 ${ }^{[15]}$. Many medical universities and colleges across the country did arrange the online classes within their own domains and students confirmed that in our study. But only $8.8 \%$ of the students agreed that these classes were quite effective; hence they rejected this mode of learning. It can be attributed to the fact that students generally lack interest in Elearning courses because they are not used to it. A recent study conducted in Bangladesh in contrary showed that students accepted elearning as mode of learning ${ }^{[16]} .69 .7 \%$ of the students were dissatisfied with this mode of elearning again contrary to a recent study ${ }^{[17]}$. Even $91.5 \%$ of the students lost their interest in studies due to online classes which was a surprising fact found by our survey. A great number of students (90.5\%) also blamed the increase use of social media as the cause of decrease study periods during COVID-19. This fact is also supported by the former study conducted at China. Including only 321 medical students, much smaller sample size than current study ${ }^{[18]}$. Increase in social media use is addictive for students as they are the sources of entertainment.E-learning should be discontinued according to the view of our survey population ( $86.4 \%$ ) because they thought that this mode of learning cannot replace the physical mode of learning as done in the classrooms. It was contrary to a previous study done by Kamal $Z$ et al., but that study was also conducted on lesser number of students as compared to our study ${ }^{[19]}$. Ward rotation was also affected badly in this pandemic as outdoor services for general public were closed in Pakistan and this led to the concern shown by the students in our survey related to future performance in wards $(89.8 \%)$. Major part of our survey population (84\%) faced difficulty in establishing boundaries between work and home routines. This finding was similar to the one found in a recently concluded study ${ }^{[20]}$. As there are other family members living in the same vicinity hence it is always difficult to create such classroom environments at home. Classroom involvement and human connection with teachers was greatly missed by the students ( $82.7 \%$ and $80.7 \%$ respectively). As there is long history of class room teaching in Pakistan and students are habitual of it. Though majority of our survey participants belonged to urban population yet $86.3 \%$ of the students showed that e-learning mode of teaching are not feasible for rural areas.

We also calculated the inferential statistics of our data by calculating prevalence rates according to MBBS classes. Our results showed statistically significant results $(p=0.045)$ when compared between MBBS classes and students' thought that this pandemic has caused more wastage of time than being useful (Table-III). Though the other results did not show statistically significant P-value yet majority of students agreed that they have lost interest now in studies. Students of senior classes were more concerned about their professional exams as they are senior most classes but the results were statistically non-significant. A previous study though showed statistically significant result for students' fears towards pandemic ${ }^{[10]}$.

Students who responded to the questionnaires also showed their fears related to this wrath of COVID-19. Students feared that there was a great difficulty for them to study at home. It could be due to non-ideal conditions for many to study at homes and could also be due to the fact that there was great panic among general public because of COVID-19 ${ }^{[21]}$. Mental impact of COVID-19 also put a huge effect on psychological status of the students as 
demonstrated by our study. It was similar to the result shown by a previous study by Waseem $M$ et al., ${ }^{[22]}$. This pandemic continued its wrath by creating a fear in our participants' minds that they themselves might get sick or could pass the disease to others as well. Many also feared the loss of their loved ones $(15.8 \%)$ especially those living abroad.

\section{CONCLUSION:}

Therefore our survey concludes that there is a negative impact of COVID-19 on medical education of the students in Pakistan as it affected them both physically and mentally.

\section{ACKNOWLEDGEMENT:}

The authors are deeply indebted to Prof. Dr. Zahid Kamal, Principal and Head, Department of Ophthalmology, Sahiwal Medical College Sahiwal for his motivation to initiate and complete this project successfully.

CONFLICT OF INTEREST: All authors disclose no conflict of interest.

\section{GRANT SUPPORT \& FINANCIAL DISCLOSURES: None}

\section{REFERENCES}

1. Sethi BA, Sethi A, Ali S, Aamir HS. Impact of Coronavirus disease (COVID-19) pandemic on health professionals. Pakistan Journal of Medical Science. 2020;36 (COVID19-S4): COVID19-S6-S11. Doi:10.12669/pjms.36.COVID19-S4.2779

2. Van Bavel JJ, Baicker K, Boggio PS, Capraro V, Cichocka A, Cikara M, et al. Using social and behavioural science to support COVID19 pandemic response. Nature Human Behaviour. 2020;1-12. Doi:10.1038/ s41562-020-0884-z

3. Furuyama TN, Antoneli F, Carvalho IM, Briones MR, Janini LM. Temporal data series of COVID-19 epidemics in the USA, Asia and Europe suggests a selective sweep of SARS-CoV-2 Spike D614G variant. arXiv preprint arXiv:2006.11609. 2020.

4. Waris A, Khan AU, Ali M, Ali A, Baset A. COVID-19 outbreak: current scenario of
Pakistan. New Microbes and New Infections. 2020:100681. Doi: 10.1016/j.nmni.2020.100681

5. Rehman ZZ, Ahmad M, Ashraf W. Multidimensional Effects of COVID-19 In Pakistan: A cross-country analysis. Journal of Research \& Reviews in Social Sciences Pakistan. 2020;3(1):788-802.

6. Sandhu P, De Wolf M. The impact of COVID19 on the undergraduate medical curriculum. Medical Education Online. 2020;25(1): 1764740. Doi: 10.1080/ 10872981.2020.1764740

7. Ahmed H, Allaf M, Elghazaly H. COVID-19 and medical education. The Lancet Infectious Diseases. 2020. DOI: 10.1016/S1473-3099(20)30226-7

8. Tariq S, Tariq S, Baig $M$, Saeed $M$. Knowledge, awareness and practices regarding novel coronavirus among a sample of Pakistani population, a crosssectional study. Disaster Medicine and Public Health Preparedness. 2020;1-20. Doi: https://doi.org/10.1017/dmp. 2020.408

9. Ikhlaq A, Hunniya BE, Riaz IB, Ijaz F. Awareness and Attitude of Undergraduate Medical Students towards 2019-novel Coronavirus. Pakistan Journal of Medical Sciences. 2020;36(COVID19-S4):32-35. Doi: $10.12669 / p j m s .36 . C O V I D 19-S 4.2636$ PMID: 32582311

10. Abbasi S, Ayoob T, Malik A, Memon SI. Perceptions of students regarding $\mathrm{E}$ learning during Covid-19 at a private medical college. Pakistan Journal of Medical Sciences. 2020;36(COVID19-S4): 79-87. Doi: 10.12669/pjms.36.COVID19-S4.2766

11. Akram W, Adeel S, Tabassum M, Jiang Y, Chandio A, Yasmin I. Scenario Analysis and Proposed PIan for Pakistan Universities-COVID-19: Application of Design Thinking Model. 2020. Cambridge Open Engage. Doi:10.33774/coe-2020ql1w6

12. Moccia L, Janiri D, Pepe M, Dattoli L, Molinaro M, De Martin V, et al. Affective temperament, attachment style, and the psychological impact of the COVID-19 outbreak: an early report on the Italian general population. Brain, Behavior, and 
Immunity. 2020: 75-79. Doi: 10.1016/ j.bbi.2020.04.048

13. Wang C, Zhao H. The Impact of COVID-19 on Anxiety in Chinese University Students. Frontiers in Psychology. 2020;11: 11681170. Doi: $10.3389 /$ fpsyg. 2020.01168

14. Hao $F$, Tan $W$, Jiang $L$, Zhang $L$, Zhao $X$, Zou $Y$, et al. Do psychiatric patients experience more psychiatric symptoms during COVID19 pandemic and lockdown? A case-control study with service and research implications for immune psychiatry. Brain, Behavior, and Immunity. 2020;87:100106.Doi: 10.1016/j.bbi.2020.04.069.

15. Shaikh MM, Dahri AS. Effect of COVID-19 epidemic on research activity of researcher in Pakistan Engineering University and its solution via technology. 3C Tecnología. Glosas de innovación aplicadas a la pyme. 2020;6(7):249-263. Doi: 10.17993/ 3ctecno.2020.specialissue5.249-263

16. Islam SD, Bodrud-Doza M, Khan RM, Haque MA, Mamun MA. Exploring COVID-19 stress and its factors in Bangladesh: A perceptionbased study. Heliyon. 2020;6(7): e04399. Doi: 10.1016/j.heliyon.2020.e04399

17. Olum R, Kajjimu J, Kanyike AM, Chekwech G, Wekha G, Nassozi DR, et al. Perspective of Medical Students on the COVID-19 Pandemic: Survey of Nine Medical Schools in Uganda. JMIR Public Health and Surveillance. 2020;6(2): e19847. Doi: 10.2196/19847 PMID: 32530815

18. Ismail NA, Lee JX, Azman $A H, N g$ JY. Reflection of connectivism in medical education and learning motivation 4 during COVID-19. medRxiv. 2020: 16711046. Doi: $10.1101 / 2020.07 .07 .20147918$

19. Aziz N, Kamal Z, Jamil AZ, Waseem M, Lail RA, Iqbal MJ. The effect of whatsapp messenger as e-learning tool on performance of undergraduate students of a Public Sector Medical College in Pakistan. The Professional Medical Journal. 2021;28(01):113-119.

20. Machado RA, Bonan PR, Perez DE, Martelli Júnior $H$. COVID-19 pandemic and the impact on dental education: discussing current and future perspectives. Brazilian oral research. 2020:34(3);34-35. Doi:10.1590/1807-3107bor-2020.vol34. 0083

21. Bandyopadhyay S, Georgiou I, Baykeens B, Gillespie CS, De Andres Crespo M, Bashir MT, et al. Medical students' mood adversely affected by COVID-19 pandemic: An interim analysis from the SPICE-19 prospective cohort study of 2075 medical students and interim foundation doctors. $2020 ; 21(7): 79-85$. Doi :10.21203/RS.3. RS-40503/V1

22. Waseem M, Aziz N, Arif MU, Noor A, Mustafa $M$, Khalid Z. Impact Of Post-Traumatic Stress Of Covid-19 On Mental Wellbeing Of Undergraduate Medical Students In Pakistan. Pakistan Armed Forces Medical Journal. 2020;70(1):S220-224.

\section{Author's Contribution:}

Nauman Aziz: Designed the study.

Muhammad Waseem: Critical revision.

Anmol Fatima: Writing the manuscript.

Aqsa Anwar: Collection of Data.

Fahad Khalid: Biostatistics.

Taimoor Asghar: Final compiling.

Submitted for publication: 27.07 .2020

Accepted for publication: 11.11 .2020

After Revision 